\title{
Practices of teaching and upbringing of young people in the Internet space
}

\author{
Valeriya Markova $^{1 *}$, Vladimir Pleshakov ${ }^{2}$, Alla Shesterina $^{3}$, and Olga Zakharyashcheva ${ }^{4}$ \\ ${ }^{1}$ Moscow City University, Institute of System Projects, Moscow, Russia \\ ${ }^{2}$ Moscow Pedagogical State University, Institute of Pedagogy and Psychology, Department of Social \\ Pedagogy and Psychology, Moscow, Russia \\ ${ }^{3}$ Voronezh State University, Faculty of Journalism, Voronezh, Russia \\ ${ }^{4}$ Center for Psychological, Pedagogical, Medical and Social Aid, Ryazan, Russia
}

\begin{abstract}
Mediatization and internetization of all areas of people's lives have become key prerequisites for the digitalization of educational practices. An increased interest in this field along with insufficient research into it has determined the relevance of this study. Its purpose is the attempt to generalize and systematize the practices developed during the authors' professional work. To achieve this purpose, the authors chose theoretical methods. They reviewed and analyzed the practices of teaching and upbringing of young people in the Internet space and audiovisual educational formats. The article deals with the practical cyberpedagogy practices of teaching and upbringing of young people in the Internet space: 1) Internet project development (Internet projecting); 2) network support of educational disciplines in social networks; 3 ) audiovisual formats in the education process; 4) remote psychological work. The authors examine the integration of audiovisual media into educational activities and the opportunities for psychological support for educational activities in cyberspace. The formats of media content used for teaching schoolchildren and students through digital technologies are specified. The authors note the positive aspects of the process of education visualization and the application of the practices and note the associated risks and ways to overcome them. The novelty of the results of this theoretical study consists in the following: the authors generalize and analyze the practices of teaching and upbringing of young people in the Internet space, conclude on the most relevant practices, examine the risks of using these practices, and propose the recommendations on how to avoid these risks. The above will allow university lecturers and school teachers, the target audience of the article, to use these practices productively and minimize the possible negative consequences.
\end{abstract}

Keywords: Internet, cybersocialization, cyberpedagogy, mediapsychology.

${ }^{*}$ Corresponding author: obydenkovavk@mgpu.ru 


\section{Introduction}

The COVID-19 pandemic and the forced distance learning of schoolchildren and students forced teachers to look for new working techniques. Previously, teachers perceived Internet technologies as additional and, if necessary, easily replaced online work with familiar faceto-face technologies. The conditions have changed and teachers have spent most of 2020 working online.

The transition to distance learning was accompanied by active visualization of the information space. Video content and audiovisual platforms have become almost the main channels for broadcasting knowledge. In the context of an overall increase in TV viewing time, which amounted to $25 \%$ in the first week of self-isolation, there was also an increase in interest in audiovisual media among young people [1]. This, along with the involvement of young people in the video production process on YouTube, Instagram, and TikTok, made it possible to talk about the relevance and naturalness of the transfer of knowledge in an audiovisual format [2].

In this regard, the need arose to generalize and systematize the practices of teaching and upbringing young people in the Internet space developed during our professional activities, which determined the purpose of the study. Research objectives: 1) to analyze and generalize original practices; 2) to research and describe audiovisual formats used in educational activities; 3 ) to compare the described original practices with the practices of other Russian and foreign authors; 4) to describe the possible risks of such practices.

\section{Methods}

We used theoretical research methods: described original practices, reviewed and analyzed scientific articles from 2016-2020 that describe such practices, and studied audiovisual educational formats.

\section{Results}

A result of this theoretical study was a list of practices for teaching and upbringing of young people in the Internet space, which can be attributed to the field of practical cyberpedagogy [3].

Cyberpedagogy and practices based on its premises consider the features of cybersocialization of people of different ages. The cybersocialization process can be roughly divided into four stages:

- "contemplative" (children from 0 to 6 years old learn the model of using digital technologies from significant adults),

- "cognitive" (children from 7 to 10 years old learn to interact with the Internet for educational activities under adult supervision),

- "active" (teenagers 11-14 years old create accounts on social networks),

- "creative" (adolescents 15-18 years old, as well as older boys and girls, can selfactualize on the Internet) [4].

Therefore, the most relevant practices for young people:

- involve the use of audiovisual content,

- enhance the educational potential of Internet resources that young people use daily,

- are implemented in an interesting environment for young people (for example, in social networks),

- promote young people's creativity and self-realization.

Let us name some examples of practices that combine the aforementioned characteristics. 


\subsection{Internet project development (Internet projecting)}

Internet projecting is "a process of planning, stepwise creation, and high-quality development of a thematic web resource that is focused on solving a particular social or professional problem" [5]. In the classroom and during independent work, students or schoolchildren create Internet projects: sites, pages on social networks, etc. The lecturer or teacher mainly performs the functions of a mentor. His or her task is not only to teach projecting but also to promote students' greater involvement in the study of the educational discipline; development of significant competencies (in the field of communication, goal-setting, and planning, using the possibilities of the Internet for learning, self-development, creativity, etc.).

\subsection{Network support of educational disciplines in social networks}

Network support of educational disciplines in social networks: "professor's" public pages and the online chat of the scientific group on Vkontakte (for example, "Cybersocialization academy \#HomoCyberus" (https://vk.com/cybersocialization) and "Cyber Academy \#Gameintraining" (https://vk.com/cyber_psytrening) by V.A. Pleshakov). These projects ensure network support of educational disciplines in the edutainment style with gamification elements.

On such "professor's" public pages:

- Thematic news is published that correlates with the content of educational disciplines. As a result, students engage in learning the disciplines not only in person but also via social networks.

- Diaries of academic events and chronicles of courses are kept. This includes the posting of photos and short videos from classes (during the COVID-19 pandemic - screenshots), students' impressions and feedback about the educational discipline as a whole and the work of the student group after each educational meeting in class. Firstly, it draws a parallel between face-to-face and distance didactic processes and also makes them more vivid. Secondly, such practice enhances academic reflexivity and promotes emotional immersion of students in the content of academic disciplines. Thirdly, this technique ensures the interaction of all students, as well as ordinary subscribers, in these public pages, which contributes to the expansion of contacts.

- Students' essays are published which contributes to the publicity and quality of reflection and improvement of authors' soft skills (particularly those associated with communication, adaptation, critical thinking, and emotional intelligence).

Such cyberpedagogical practices ensure the trinity:

- creating conditions for the formation of intelligence and psychophysical and spiritual forces of a person in the context of cybersocialization (cyberupbringing),

- a person's transfer and assimilation of the knowledge and experience of mankind in the context of cybersocialization (cyberlearning),

- achieving the goals of cyberdevelopment, cyberupbringing, and cybereducation.

\subsection{Audiovisual formats in the education process}

The analysis of educational video content indicates the activation of the practices of integrating video content into the education system that already existed before the COVID19 pandemic. The most common forms include:

- recorded video lectures,

- live broadcasts of training sessions,

- webinars, 
- video tours,

- video conferencing,

- training videos in the video blogging system (mainly in the life hack genre).

Apart from these traditional forms, there are relatively new forms based on:

- using VR technologies in the learning process,

- integration of gamification elements using video content in the education process,

- replacing real processes with their video display (for example, museum guided tours, etc., as well as proposals to complete tasks in video format).

An example of the integration of video formats into the education process can be the project "Mediapsychology" by Prof. A.M. Shesterina (YouTube-channel "Alla Shesterina" (https://www.youtube.com/channel/UCABivzmd1-EfygiW3S2ShxA) and the community "Mediapsychology" in the social network Vkontakte (https://vk.com/public21211663). Within the framework of the project, cycles of videos of various formats are created: from traditional video lectures to vlogs and experimental training videos. The materials are aimed at increasing the media literacy of the population in general and the formation of professional knowledge on media production among students of specialized training areas. The videos cover three main types of video content that are recommended for online posting: hub, help, and hero (regular, situational, and exclusive video content).

\subsection{Remote psychological work}

The success of educational activities also depends on the psycho-emotional well-being of schoolchildren and students. New practices of remote psychological work are emerging, in particular, based on the features of their cybersocialization.

In particular, the specialists from the Center for Psychological, Pedagogical, Medical, and Social Aid (http://center-pmpk.ru/) rely on the cyberontological approach in education [6] and apply the features of online consulting, diagnostics, correction, and prevention.

For diagnostic work, services with valid, reliable methods of psychological diagnostics are used. For online consulting one should use secure communication channels or Skype. The use of instant messengers is not recommended to comply with the principle of confidentiality.

Correctional work is carried out through Zoom and Google Meet, which makes it possible to use stimulating material by showing presentations.

Preventive work consists of preparing materials for the various specialized communities, both parent-based and professional. For adolescents, psychological online-quests are used (games specially developed by psychologists and implemented in cyberspace).

\section{Discussion}

When generalizing and describing original examples of teaching and upbringing of young people in the Internet space, one should draw parallels with some other Russian and foreign practices.

First, one should note the review of research from 2009-2018 that confirms the interest in online education in general [7].

Some authors describe social networks and messengers as a "digital educational network for teaching and learning" [8] and cite data that teachers use such networks for self-education and professional communication with colleagues [9-13]. Students also use social media and messengers for educational purposes, including collaborative work [14-16]. Students engage in joint online [17-18], project, and research activities [19-20]. Many integrate video resources posted on educational platforms or social media into the educational process, which is consistent with general trends in the visualization of information exchange [2, 21-23]. 
It is important to note that many of the practices of teaching and upbringing of young people in the Internet space have limitations and entail risks.

The distance learning format requires increased self-organization from students [24-25]. Screen consumption of information, with all its efficiency, can also have side effects affecting people's physiological, psychological, and mental health [26-28].

With the active use of video technologies, one can face barriers to the transmission of information: technical and technological, contra-suggestive, emotional, ethical, thesaurus, psychological, overload barrier, and others [29]. This makes it difficult to use traditional formats of distance learning on a large scale. As a result, there is a situation where a person simultaneously suffers from an overabundance of information and a feeling of inability to find the necessary information. Media addiction can form. Some online practices are also associated with reputational risks (unplanned recording of video lectures by listeners, uploading fragments taken out of context online, etc.).

\section{Conclusion}

We examined the practice of teaching and upbringing of young people in the Internet space. The associated risks make one consider prevention measures. Summarizing the recommendations proposed by various researchers and considering the experience, we suggest the following:

1. To adapt models of distance learning using video not only to the tasks of educational activities but also to students' technical and technological capabilities (with a variation of the synchronous and asynchronous models).

2. To introduce mechanisms for certification of educational video content.

3. To integrate the rules of information and media hygiene and culture of cybersocialization, as well as the principles of digital detox, into the process of teaching and upbringing (for example, to take frequent breaks, use fact-checking during studying, etc.).

4. To disseminate digital security practices that ensure the preservation of the reputation of the teacher and students in the process of educational activities and psychological work.

The prospect of the study may be the development of more detailed recommendations that will reduce the risks arising from the use of the described practices.

\section{References}

1. A.M. Shesterina, Homo Cyberus, 1(8) (2020). Accessed on: December 20, 2020. [Online]. Available: http://journal.homocyberus.ru/Shesterina_AM_1_2020

2. A.G. Kachkaeva, S.A. Shomova, Multimediinaya zhurnalistika [Multimedia journalism] (Higher School of Economics Publishing House, Moscow, 2017)

3. V.A. Pleshakov, Teoriya kibersotsializatsii cheloveka [The theory of human cyber socialization] (Moscow Pedagogical State University, Homo Cyberus, Moscow, 2011)

4. O.A. Zakharyashcheva, Homo Cyberus, 1(6) (2019). Accessed on: December 20, 2020. [Online]. Available: http://journal.homocyberus.ru/ZahariyashchevaOA_1_2019

5. V.K. Obydenkova, Mir Nauki. Pedagogika i Psikhologiya [World of Science. Pedagogy and Psychology], 4(6) (2016). Accessed on: December 20, 2020. [Online]. Available: http://mir-nauki.com/PDF/75PDMN616.pdf

6. O.I. Voinova, V.A. Pleshakov, Kiberontologicheskii podkhod v obrazovanii [Cyberontological approach in education] (Norilsk Industrial Institute, Norilsk, 2012)

7. F. Martin, T. Sun, C.D. Westine, Computers \& Education, 159 (2020). https://doi.org/10.1016/j.compedu.2020.104009 
8. S. Manca, The Internet and Higher Education, 44 (2020). https://doi.org/10.1016/j.iheduc.2019.100707

9. N. Kelly, A. Antonio, Teaching and Teacher Education, 56, 138-149 (2016) https://doi.org/10.1016/j.tate.2016.02.007

10. M. Rehm, A. Notten, Teaching and Teacher Education, 60, 215-223 (2016). https://doi.org/10.1016/j.tate.2016.08.015

11. J.P. Carpenter, S.A. Morrison, M. Craft, M. Lee, Teaching and Teacher Education, 96 (2020). https://doi.org/10.1016/j.tate.2020.103149

12. G.S. Gorozidis, Y.S. Tzioumakis, C. Krommidas, A.G. Papaioannou, Teaching and Teacher Education, 96 (2020). https://doi.org/10.1016/j.tate.2020.103184

13. C. Shelton, R. Curcio, S. Schroeder, Instagramming their hearts out: Teacher influencers on Instagram, in Proceedings of Society for Information Technology \& Teacher Education International Conference, Association for the Advancement of Computing in Education, 7 April 2020, Waynesville, NC, United States (2020)

14. S. Dahdal, Journal of Educational Technology Systems, 49(2), 239-249 (2020). https://doi.org/10.1177/0047239520928307

15. A. Erarslan, Turkish Online Journal of Educational Technology, 18(3), 54-69 (2019)

16. A.G. Kukushkina, European Proceedings of Social and Behavioural Sciences, 87, 310319 (2019). https://doi.org/10.15405/epsbs.2020.08.02.39

17. E.D. Patarakin, S.N. Vachkova, Vestnik MGPU. Pedagogika i psikhologiya, 4, 101112 (2019). https://doi.org/10.25688/2076-9121.2019.50.4.09

18. E.D. Patarakin, Obrazovatelnye tekhnologii i obshchestvo, 3, 309-329 (2017)

19. E.K. Samerkhanova, E.P. Krupoderova, K.R. Krupoderova, L.N. Bahtiyarova, A.V. Ponachugin, International Journal of Environmental \& Science Education, 1, 45784586 (2016)

20. M.V. Yarmolinskaya, Internet-proyekt kak instrument formirovaniya otvetstvennosti starshego podrostka [Internet project as a tool for forming responsibility of an older teenager], Thesis (Herzen Russian State Pedagogical University, Saint Petersburg, 2016)

21. A.A. Amzin, Osobennosti mediapotrebleniya [Characteristics of media consumption] (2016). Accessed on: December 20, 2020. [Online]. Available:

http://newmedia2016.digital-books.ru/kniga/osobennosti-mediapotrebleniya/

22. E.L. Vartanova, MediaAlmanakh, 2(85), 8-16 (2018)

23. S.N. Ilchenko, Mediascope, 4 (2016). Accessed on: December 20, 2020. [Online]. Available: http://www.mediascope.ru/2237

24. E.V. Bezvikonnaya, N.A. Bibikova, Problemy i perspektivy primeneniya distantsionnykh tekhnologii v protsesse obucheniya po programmam dopolnitelnogo obrazovaniya [Problems and prospects of using distance technologies in the learning process for additional education programs], in Procceedings of the 2nd regional scientific and practical conference "Molodezh' v global'noy seti: problemy, vyzovy, vozmozhnosti, perspektivy", 3 December 2015, Omsk, Russia (2016)

25. J. Littenberg-Tobias, J. Reich, The Internet and Higher Education, 47 (2020). https://doi.org/10.1016/j.iheduc.2020.100759

26. Yu.D. Babaeva, A.E. Voiskunskii, Psikhologicheskiy zhurnal, 1, 89-100 (1998). Accessed on: December 20, 2020. [Online]. Available: https://cyberpsy.ru/articles/babaeva_vojskunskij_posledstviya_informatizatsii/

27. M.M. Druker, Znak. Problemnoe pole mediaobrazovaniya, 1, 15-224 (2020) 
28. S. Livingstone, New Media Society, 10(3), 393-441 (2008)

29. A.M. Shesterina, Psikhologiya zhurnalistiki [Psychology of journalism], Part 1 (Voronezh State University Publishing House, Voronezh, 2011) 